特 集 $2 *$

\author{
逆流性食道炎の診断と治療 \\ 一逆流性食道炎の発生機序を中心に一 \\ 慶応がんセンター \\ 幕内 博康 熊谷 義也 山崎 栄龍 \\ 慶応義熟大学外科学教室 \\ 掛川暉夫夫片桐誠 \\ 国立東京第 2 苪院外科 \\ 有森 正 樹
}

\title{
DIAGNOSIS AND THERAPY OF REFLUX ESOPHAGITIS
}

\section{Hiroyasu MAKUUCHI, Yoshiya KUMAGAI and Eiryu YAMASAKI \\ Keio Cancer Center}

Teruo KAKEGAWA and Makoto KATAGIRI

Department of Surgery, School of Medicine, Keio University

Masaki ARIMORI

Department of Surgery, The II Tokyo National Hospital

\begin{abstract}
逆流性食道炎の発生機序は LESP が低く, かつ gastrin に対する反応の悪いものに逆流が 起こり, 逆 流液が長く食道内に停膟することによると考兄られる.これに腹圧と逆流液の酸度が影響を及ぼしてい る. この仮説を食道内压 $\mathrm{pH}$ 測定，gastrin 負荷試験，酸排出試験を施行して確かめた，逆流性食道炎の 診断には食道内視鏡が最も重要であるが，食道炎の予後を知るにはこれらの機能検查が必要である.

逆流性食道炎の治療は原則として保存的に行い，（1）ファーラー位で上体を高くして寝る.（2）食 後 3 時間以上たってから床につく，（3）LESP を上昇させる薬阂の投与，（4）制酸剤粘膜保護剂の投 与，（5）肥満があれば標準体重へ戻す。などが有効である.
\end{abstract}

索引用語：逆流性食道炎, 食道内圧測定, 酸排出試験, gastrin 負荷試験, 食道裂孔へルニフ

I はじめに

近年, 体位の欧米化や食道噴門部への医学的関心が增 したことなどにより，逆流性食道炎が問題としてとり上 げられる機会が多くなった．逆流性食道炎は消化液が食 道内へ逆流することにより発生し，胸焼け，胸骨後方 痛, 燕下困難感などの症状とともに, ときとして食道潰 瘍からの出血，痏痕狭窄などをきたすこともある，逆流

* 第13回日消外総会シンポII 逆流性食道炎をめぐる諸問題
なくして逆流性食道炎は発生しないが，逆流が起こって も必ずしも食道となるわけではない，小児の頃から食後 すぐに横になると口腔までミソ汁などが戻ってくるが， 内視鏡的に食道炎が認められず症状もないという症例も ある. われわれは逆流性食道炎の発生機序を LESP が 低く，かつ，gastrinに反応の悪いものに逆流が扢こり， その逆流液が長時間食道内に停滞することによる，と考 えている $\mathrm{pH}$ 測定, gastrin 負荷試験, 酸負荷および排出試験を施 行して逆流性食道炎の診断を行い，われわれの逆流性食 
道炎発生機序についての仮説を検討した。さらに，胃液 の酸度, 肥満, 食道裂孔へルニアなどと食道炎との関係 について調查研究し，治療についての方針を定めた。

\section{II 研究対象および方法}

最近, 当センターで食道造影を施行し, 内視鏡検査で 食道疾患研究会分類による食道炎の診断を行った65例に 食道内圧 $\mathrm{pH}$ 湘定を施行して対象とした. 内分けは食道 炎の認められない 0 度群27例, I 度群22例, II 度群16例 である. 食道造影は Buscopan 2A 筋注, 発泡剂服用後 第 1 斜位第 2 斜位で 2 重造影を行い, Barium $300 \mathrm{ml}$ 服 用後背臥位で逆流叔よび食道裂孔へルニアの有無を険討 した. 食道ファイバースコープ検查はオリンパス社製 GIF-P $\mathrm{P}_{2}, \mathrm{EF}-\mathrm{B}_{3}$ を使用し, 咽頭麻醉後, 食道裂孔へルニ アの有無扰よび食道炎の有無と程度分類を施行した，食 道内圧 $\mathrm{pH}$ 測定検査では, 内压は内径 $1.2 \mathrm{~mm}$ のポりエ チレンチューブの先端を閉塞し側孔を開け open-tip と 乙, $0.2 \mathrm{ml} / \mathrm{m}$ の速度で infusion 法を用い, $5 \mathrm{~cm}$ 間隔 2 チャンネルを使用して低圧用 transducer に接続した。 $\mathrm{pH}$ 測定は微小ガラス電極を内压チューブ2 本と束ねて

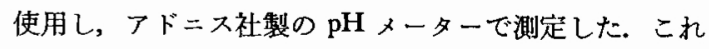
らを呼吸波とともに東芝 R 10A 型 polygraph で記録し た. Gastrin 負荷試験は tetragastrin $4 \gamma / \mathrm{kg}$ を静注負荷し た後，数回の引抜き法による LESP を測定した，酸負 荷及び酸排出試験は内圧チューブを LES より $5 \mathrm{~cm}$ 口側 に固定し，0.1N-HCl $5 \mathrm{ml}$ を注入して症状及び curling の出現の有無を調べ，その後空显下を10回施行させ $\mathrm{pH}$ 5.0 以になるまでの回数を調べた。 さらに，食道内視鏡 で食道炎の診断を行った126例を対象に，その身長体重 から松木式標準体重表を用いて肥満と食道炎の関係につ き検討した. また，食道内視鏡で食道裂孔へルニア及び 食道炎の診断を行った568例を対象として，食道裂孔へ ルニアと逆流性食道炎の関係を調べた。

\section{III 研究成續}

（1）下部食道括約帯圧 lower esophageal sphincter pressure (LESP) (図1)

食道炎の認められない0度群27例では14.0

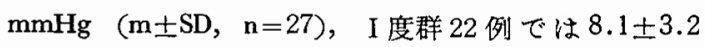
$\mathrm{mmHg}(\mathrm{m} \pm \mathrm{SD}, \mathrm{n}=22)$, II 度群 16 例では8.1 83.7 $\mathrm{mmHg}(\mathrm{m} \pm \mathrm{SD}, \mathrm{n}=16)$ となり, 無食道炎群は有食道炎 群より有意差 $(\mathrm{p}>0.001)$ をもって压が高い. I 度群と II度群の間に差は認められない。

（2） Gastrin 負荷試験（図 1）

tetragastrin $4 \mathrm{r} / \mathrm{kg}$ 静注負荷を行いLESP の変化を
図 1 逆流性食道炎とLESP 及び gastrin 負荷試験

\section{LESP}
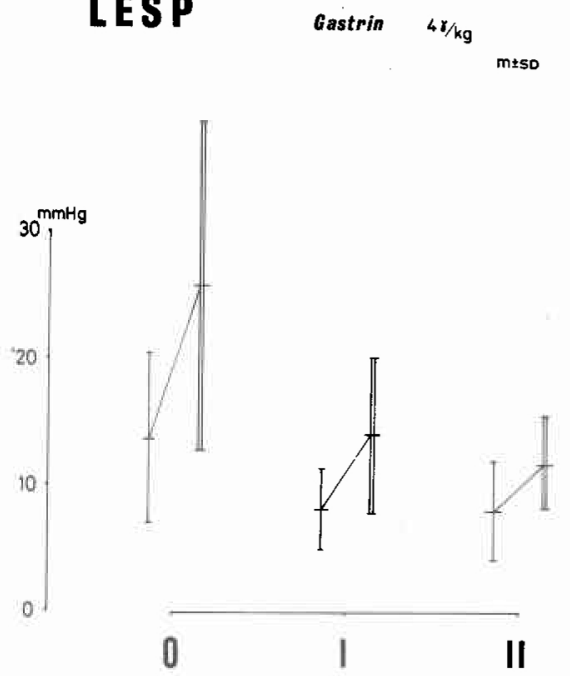

图 2 Acid clearing test : : 段良好例 下段不良例 acid PERfusion \& CLEaring test

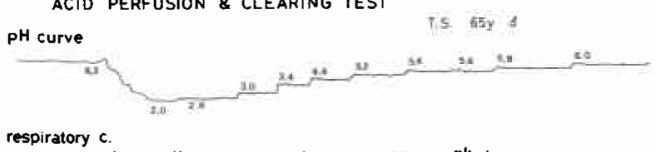

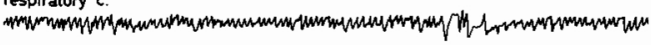
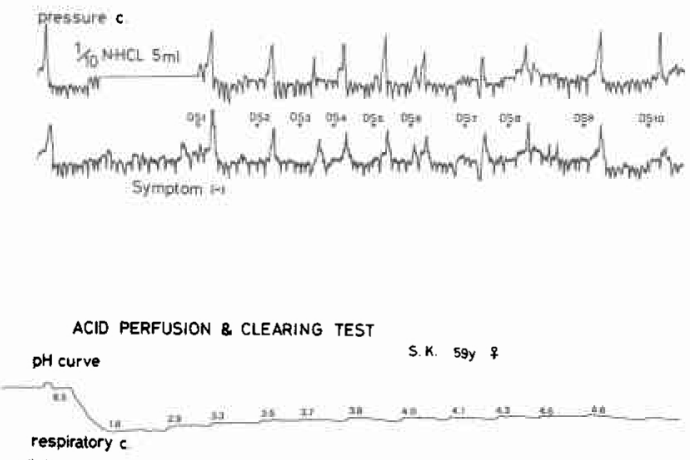

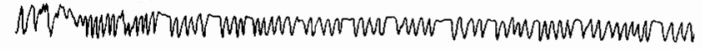

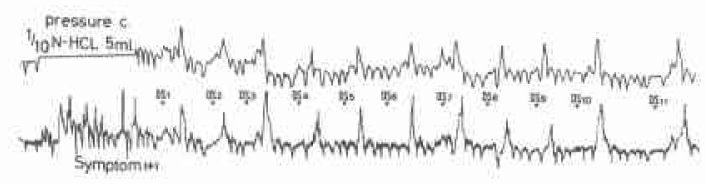

みると，食道炎 0 度群 $14.0 \pm 6.6 \mathrm{mmHg}$ から $25.7 \pm 12.7$

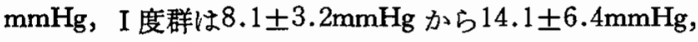
II 度群は8.1士3.7mmHg から $11.9 \pm 3.6 \mathrm{mmHg}$ と，それ ぞれ圧が上昇した。 0 度群とI 度群では $\mathrm{p}<0.001$ で有意 の圧の上昇を認めるが， II 度群には有意差を認めない。 
（3）酸排出試験，acid clearing test（図 2，3）

$0.1 \mathrm{~N}-\mathrm{HCl} 5 \mathrm{ml}$ 負荷後，空燕下を施行させて $\mathrm{pH} 5.0$ 以上に上昇する回数をみると，食道炎 0 度群では 5 回以 下の症例が27例中17例63.0\%，I 度群では $6 \sim 8$ 回の空 鯃下を要するものが22例中13例63.6\%を占めた。

II 度群では16例中13例 $81.3 \%$ 10 回以上の空燕下を必要 とする排出能の悪い症例で占められた。

（4）胃内 $\mathrm{pH}$ と逆流性食道炎（図 4)

胃内 $\mathrm{pH}$ と逆流性食道炎の間に一定の傾向は見い出 し得ない.

（5）肥満と逆流性食道炎（表 1 ）

標準体重を $10 \%$ 以上超過する肥満例は食道炎 0 度群で 48 例中 8 例 $16.7 \%$, I 度群で36例中 8 例 $22.2 \%$, II 度群 で32例中 6 例 $18.8 \%$ となり，肥満と逆流性食道炎との間 に特别の関係は見られない

（6）食道裂孔へルニアと逆流性食道炎（表 2）

食道内視鏡観察により食道裂孔により狭小となってい る部位より上方に $5 \mathrm{~cm}$ 以上の胃粘膜に覆われた襄状部

図 3 Acid clearing test

\begin{tabular}{|c|c|c|c|c|c|c|c|c|c|c|}
\hline somentis & 1 & 2 & 3 & 4 & 5 & 8 & 7 & 8 & 8 & $10-$ \\
\hline 0 & & . & •• & :ः & $\therefore$ & & $\bullet$ & • & • & ..... \\
\hline I & & & . & ... & - & $\therefore$ & • & 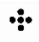 & - & •• \\
\hline II & & & & & & & & 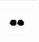 & . & :ं:ँ: \\
\hline
\end{tabular}

図 4 逆流性食道炎と胃内 $\mathrm{pH}$

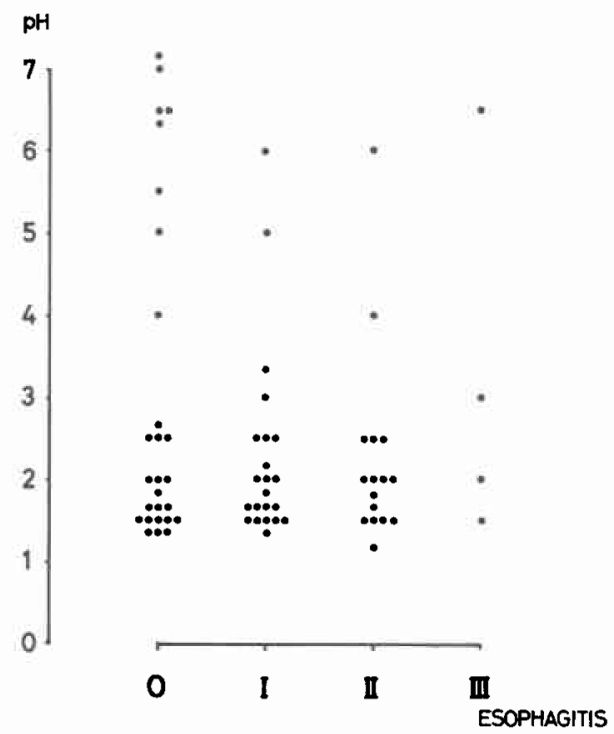

表 1 肥满と逆流性食道炎

\begin{tabular}{|c|c|c|c|c|}
\hline $\begin{array}{c}\text { 会道炎 } \\
\text { 集体 }\end{array}$ & 0 & I & II & III \\
\hline$-10 \%$ & 6 & 4 & 3 & 2 \\
\hline$+10<<+10$ & 34 & 24 & 23 & 4 \\
\hline$+10 \leqq$ & 8 & 8 & 6 & 4 \\
\hline it & $48.7 \%$ & $22.2 \%$ & $18.8 \%$ & $40.0 \%$ \\
\hline
\end{tabular}

表 2 食道裂孔へルニアと逆流性食道炎

\begin{tabular}{|c|c|c|c|c|c|}
\hline \multirow{2}{*}{ 道资 } & \multirow{2}{*}{ A } & \multicolumn{2}{|c|}{ 疑彭 } & \multirow{2}{*}{$\begin{array}{c}\text { 正 常 } \\
0\end{array}$} & \multirow{2}{*}{ 都 } \\
\hline & & B & C & & \\
\hline 0 & $\begin{array}{l}36 \\
15.3 \%\end{array}$ & 78 & 43 & 79 & 236 \\
\hline I & $\begin{array}{l}50 \\
26.3 \%\end{array}$ & 75 & 31 & 34 & 190 \\
\hline II & $\begin{array}{l}45 \\
45.9 \%\end{array}$ & 31 & 12 & 10 & 98 \\
\hline III & $\begin{array}{l}13 \\
29.5 \%\end{array}$ & 19 & 8 & 4 & 44 \\
\hline
\end{tabular}

分を認めるものをへルニア確診，（A）とすると，食道 炎 0 度群では236例中36例15.3\%，I 度群では190例中50

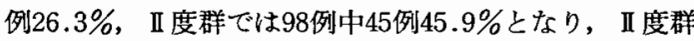
が $\mathrm{p}<0.01$ で有意に多いと言える.

\section{IV 考 察}

逆流性食道炎の診断には，（1）上部消化管造影, （2）食道内視鏡，（3）食道生検，（4）食道内圧 $\mathrm{pH}$ 測定，などの方法がある. 上部消化管造影では逆流お よび食道裂孔へルニアの有無と食道潰瘍や狭窄の診断 に有用であるが，I度の食道炎の診断は困難な場合が 多い。食道内視鏡は食道炎の存在診断上久とことのでき ない検査法であり, 程度分類, 食道裂孔へルニアの診断 も可能で, 最も重要である. 食道生検は病理学的裏付け がとれ，悪性疾患との鑑別に有用であるが，I 度の食道 炎では内視鏡所見との不一致例も多い.Pope, C.E. ${ }^{2)}$ 女 同一症例でも診断法により異なることが多いことを示 摘している.この原因の 1 つに，生検鉗子では粘膜上皮 のみで粘膜下增を含めて採用することが困難なことがあ る.われわれは cup 長 $3.5 \mathrm{~mm}$ の大生検鎮子を開発し て診断能を上げている．さて，食道炎の予後を知り治療 方針や手術適応を決めるには食道内圧 $\mathrm{pH}$ 測定が必要 であり, gastrin 負荷試験, 酸排出試験も併用すべきで 
ある. Shinner, D.B. \& Demeester, T.R. ${ }^{3)}$ も逆流性食 道炎の診断や治療効果の判定に食道内圧測定が必要であ ると述べている.

逆流性食道炎は逆流なくしては発生しないが，逆流が 存在しても必ずしも食道炎となるわけではないと考光 る. 逆流液が食道内へ停滞することが必要であり，排出 能（wash out）の良い症例はひどい食道炎とならないが， 排出能の悪い症例は治療しないと潰瘍からの出血, 瘚痕 狭窄など重篤な合併症を拈こす可能性がある. Hendrix， T.R.4) む wash out の重要性炕つき言及している。

まず，逆流がおこるためには LESP が低く，かつ， gastrinに対する反応が悪いことが必要であると考光る. 有食道炎群は無食道炎群より有意心 LESP が低く，ま た，食道炎四度群は gastrin に対する反応が悪かった。 Scheurer, U. \& Halter, F. ${ }^{5}$ \& 39 例 に LESP 測定と gastrin 負荷試験を施行して，われわれと同様の結果を 得ている.さて，LESP はどれだけあれば正常といえる かは, チューブの内径, infusion のスピードで異なるら 光，腹圧とのバランス関係にもあるので決定は困難であ るが，われわれは一応10 $\mathrm{mmHg}$ 以上あれば正常とし た. gastrin に対する LES の反応については，Higgs， R.H.6) のように内因性 gastrin は LESP に影響を及注 さないと報告するものもあるが，gastrin は LESPを上

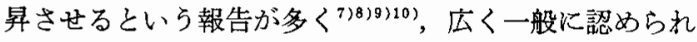
ている.とくに，摂食後は胃内容が増加し最も逆流が起 こりやすい時期で，生体は gastrin を分泌して LESPを 上昇させ逆流を防止している，食後の LESP の上昇が 認められない症例では2つの場合が考点られる.1つは gastrin 分泌が悪いこと，むう 1 つは LES の gastrin に 対する反応が悪いことである．まだ症例が少なく，断定 的なことはい党ないが，無食道炎群と有食道炎群の空腹 時血中 gastrin 值に差は認められない。また，摃食後の 血中 gastrin 值については覞在検討中である. 今回は外 因性 gastrin に対する LES の反応をみたわけであり， 内因性 gastrin に対する LES の反応と全く同様である とすることはでさないが, LES 機能の一端を知ること がでさたと考える.

つぎに，逆流夜の食道内停滞であるが，逆流してもす ぐ排出される症例では食道炎は起こらないし，常に立 位や坐位で生活すれば逆流は起こりにくく排出は容易で 食道炎ともならない，酸排出試験の結果では食道炎 0 度群では 5 回以下の空燕下で $\mathrm{pH} 5.0$ 以上に上昇する症 例が半数以上を占めているが，10回以上の空嬿下を要す
表, 3 逆流性食道炎

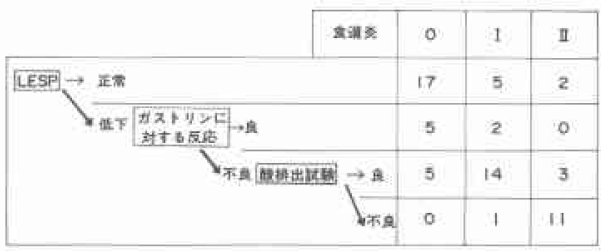

る酸排出能不良例む 6 例 $22.2 \%$ に認められた. これらの 症例を検討してみると，いずれも LESP が10 $\mathrm{mmHg}$ 以 上あり，かつ，gastrin負荷試験で反応の良い症例であっ た. 逆流しにくい症例であれば酸排出能が不良であって も食道炎にならないわけである。皇こで, LESP, gastrin 負荷試験, 酸排出試験の結果をまとめて，われわれの食 道炎発生機序の仮説にあたってはめてみた（表 3）食道 炎 0 度群では LESP が10 $\mathrm{mmHg}$ 以上で一応正常とみな されたものが17例 $63.0 \%$ ，LESP は低いが gastrin 負荷 で前值の 2 倍以上飞 LESP が上昇する反応の良いもの が 5 例 $18.5 \%$ を占め, 計22例 $81.5 \%$ が逆流しにくい症例 で占められている．逆流はするが酸排出能の良い症例が 5 例 $18.5 \%$ であった。食道炎 I 度群では LESPが低く， gastrin に対する反応も悪く逆流し易いが，酸排出能の 良い症例が14例63.6\%を占めている。酸排出試験も不良 である症例が 1 例 $4.5 \%$ あが，この症例は胃内 $\mathrm{pH}$ が 6.0で低酸であったために食道炎が軽度にとと゚まったる のと推測され，逆流液の酸度も食道炎発生に大きな影響

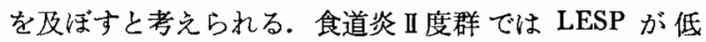
く, gastrin に対する反応が悪く, 酸排出試験不良例が 11例68.8\%を占めている. しかし， LESPが 10 $\mathrm{mmHg}$ 以 上の症例が 2 例 $12.5 \%$ に認められたが，いずれも gastrin に対寸る反応が悪く，から，酸排出能不良例であった. さらに耐症例共, 標準体重を20\%以上超過する肥満例飞 よる腹圧の上昇が大きな影響を及ぼしていると考えられ た. 酸排出能良好例が 3 例18.8\%に認められたが，これ

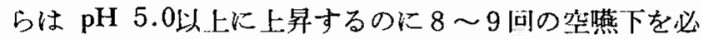
要とした将:例であった。

そこで，逆流性食道炎発生に影響を及ぼしている．俏 液の酸度, 肥満, 食道裂孔へルニア, との関係を検討し た.

胃液検查が不充分であるため, 胃内の $\mathrm{pH}$ をみたが, 食道炎の程度との間に一定の関保は見い出せなかった。 食道炎 II 度群での胃内 $\mathrm{pH}$ 高值例では内視鏡検查時に胆 汁の胃内逆流が認如れ，十二指腸内容の逆流による $\mathrm{pH}$ 上昇が考壳られる. 一方, 食道炎 0 度群, I 度群で 
图 5 metoclopramide $0.2 \mathrm{mg} / \mathrm{kg}$, sulpiride $1 \mathrm{mg} / \mathrm{kg}$, domperidon $0.2 \mathrm{mg} / \mathrm{kg}$ 静注負荷による LESPの 変化

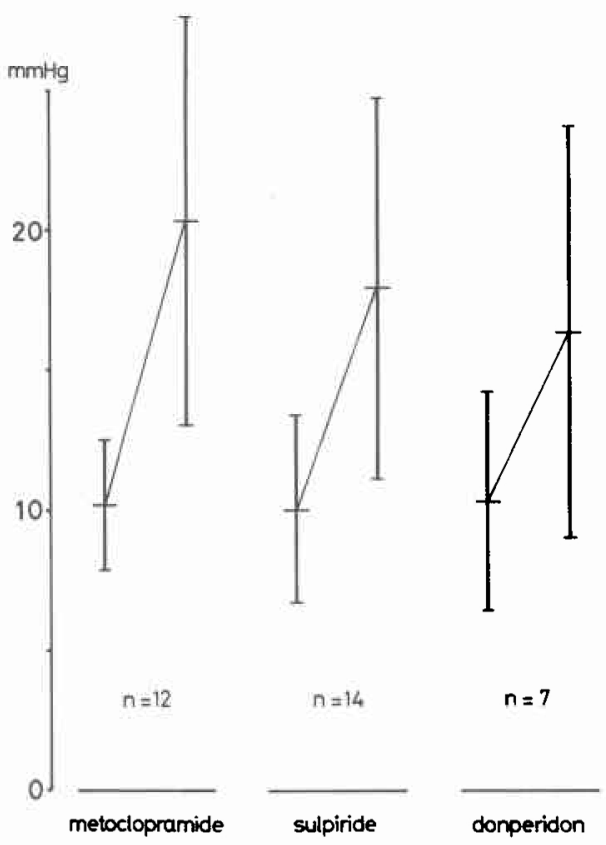

图 6 逆流性食道炎発生機序

\section{$\left\{\begin{array}{l}\text { LESPの低下 } \\ \text { カストリンに対するLESの反応不良 }\end{array}\right.$}

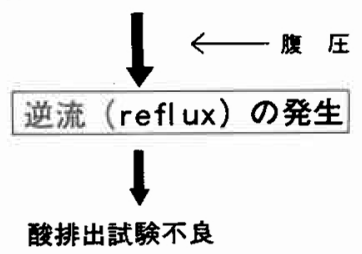

(acid clearing test)

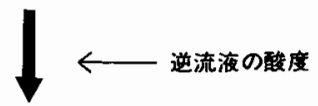

逆流性食道炎

の胃内 $\mathrm{pH}$ 高値例の中には LESP が低く, gastrin $に も$ 反応の悪い逆流症例むあり，低酸であるために高度の食 道炎とならないものと考えられる，胃液の酸度も食道炎 発生の一要素となっている.

肥満との関係をみると, 食道炎群にやや肥満例が多い が有意差はない，肥満による腹圧の上昇は LESP とバ ランス関係にあり，LESP が正常範囲であるのに食道炎
を起こしている肥満例では，体重を減少させることによ り，その改善を図ることができると考える。

食道裂孔へルニアの合併率をみると，食道炎 II 度群 では有意差をもって食道裂孔ヘルニアの合併率が高かっ た。食道裂孔へルニア症例には食道炎を念頭に入れて対 処せねばならないが，へルニて症例にも充分な LESP を有し，食道炎の認められない症例も少なくない。

さて，食道炎の治療には保存的療法と手術的療法が西 るが，本邦では手術の適応となる症例は極めて少ない。 われわれの施設で昭和 42 年から53年までに定期的に上部 消化管検診を受けている会員約13,000名中，内視鏡的に 食道炎と診断されたるのは513例であるが，この5ち手 術の適応となったものは 6 例1.17\%にすぎない。また， 逆流性食道炎から狭窄をきたし，PSD を使用して経内 視鏡的に狭窄部を切開し, 以後保存的に治療して経過良 好なるのる 4 例ある. 手術々式は Nissen 法を標準術式 としている. 保存的治療としては逆流の防止と逆流液の 速やかな排出を図るために次のような方法をとってい る.（1）ファーラー位で上体を高くして寝る。（2） 食後 3 時間以上してから床につく（3）LESP を上昇 させる蒋剤の投与. (4) 制酸剤, 粘莫保護剤の投与.

（5）肥満があれは標準体重へ戻す，このうち，LESP を上昇させる薬剤であるがわれわれはmetoclopramide, sulpirideの服用を施行して括り，さらに， domperidon も 試みたいと考えている．これら薬風の LESPに対する効 果をみるために, 21〜24歳の男性志願者33名に metoclopramide $0.2 \mathrm{mg} / \mathrm{kg}$, sulpiride $1 \mathrm{mg} / \mathrm{kg}$, domperiden 0.2 $\mathrm{mg} / \mathrm{kg}$ の静注負荷を施行し LESP 測定した（図 5 ). metoclopramide は $10.2 \pm 2.3 \mathrm{mmHg}$ から $20.3 \pm 7.3$ $\mathrm{mmHg}(\mathrm{m} \pm \mathrm{SD}, \mathrm{n}=12)$ sulpiride $410.0 \pm 3.4 \mathrm{mmHg}$

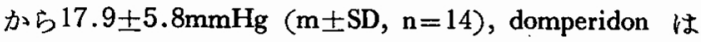
$10.3 \pm 3.9 \mathrm{mmHg}$ から $16.3 \pm 7.4 \mathrm{mmHg}$ とそれぞれ有意 の圧の上昇を認めた． ほとんどの症例が保存的に加療し 得るものと考觉られる。

\section{$\mathbf{v}$ おわりに}

逆流性食道炎の発生機序は，LESP が低く，かつ， gastrin に対する反応の悪いるのに逆流がおこり，これ には腹圧が関与している. 逆流が起こって, 逆流液が食 道内に停滞し，かつ，逆流液の酸度が強いものに逆流性 食道炎が発生すると考兵た。この仮説を, 食道内圧 $\mathrm{pH}$ 測定, gastrin 負荷試験, 酸排出試験を施行して確かめ た（図5）。

逆流性食道炎の診断には食道ファイバースコープ検査 
が最も重要であるが，食道炎の予後を知るには，食道内 圧 $\mathrm{pH}$ 測定など機能検査が必要である.

逆流性食道炎の治療は原則として保存的に行い，（1） ファーラー位で上体を高くして寝る.（2）食後 3 時間 以上たってから床につく（3）LESP を上昇させる薬 剤の投与，（4）制酸剤粘膜保護剤の投与，（5）肥満 があれば漂準体重へ戻す。などが有効である。

\section{文献}

1) 幕内博康他：食道内 $\mathrm{pH}$ 圧測定に上る逆流性食 道炎の発生機序に対する検討. 日平滑筋誌, 14 (4) : 218-219, 1979.

2) Pope, C.E.: Pathophysiology and diagnosis of reflux esophagitis. Gastroenterology, $70(3)$ : 445-454, 1976.

3) Skinner, D.B. and Demeester, T.R.: Gastroesophageal reflux. Curr. Probl. Surg., 13(1): $62,1976$.

4) Hendrix, T.R. and Yardley, J.H.: Consequences of gastroesophageal reflux. Clin. Gastroenterol., 5(1): 955-974, 1976.
5) Scheurer, U. and Halter, F.: Lower esophageal sphincter in reflux esophagitis. Scand. J. Gastroent., 11(6): 629-634, 1976.

6) Higgs, R.H.: Gastric alkalinization. Effect on LESP and serum gastrin. New Engl. J. Med., 291(10): 486, 1974.

7) Lipshutz, W.: A comparison of the site of action of gastrin I and LES and antral circular smooth muscle. Gastroenterology, 61(4): 454, 1971.

8) McCall, W.: Relationship between changes in plasma gastrin and lower esophageal sphincter pressure after meals. Br. J. Surg., 62: 15-18, 1975.

9) Lipshutz, W.: Physiological Determinations of LES function. Gastroenterology, 61(1): 16, 1971.

10) Raymond, L.: Mesurements and comparisons of lower esophageal sphincter pressures and serum gastrin lebels in patients with gastroesophageal reflux. Gastroenterology, 67(3): $415,1974$. 